\title{
ARCHAEOLOGICAL REVOLUTION(S)
}

Alfredo González-Ruibal

Institute of Heritage Sciences - Spanish National Research Council (Incipit-CSIC)

Avenida de Vigo s/n, 15705 Santiago de Compostela, Spain

alfredo.gonzalez-ruibal@incipit.csic.es

I understand Kristian Kristiansen's enthusiasm for the seemingly infinite possibilities offered by the collaboration between the natural sciences and archaeology. Gone are the days when archaeometry was associated with a narrow, functionalist agenda. We know now that we can recover past habitus, memory or social identity through the application of "archaeological science". (I hate the concept, though: is it not science when we do not use a microscope?) I also agree with his plea for a return to the production of grand narratives. In fact, I have always been a great fan of his masterful grand narrative: Europe before History (Kristiansen 1998). The approach proposed in this article, however, does not reject the small and the local. On the contrary, it tries to bridge the gap between the micro and the macro, bypassing an unhelpful dichotomy. I also find very revealing the historiographic analysis proposed by the author. Nevertheless, I have some misgivings about his paradigmatic enthusiasm that I will try to flesh out in this comment.

My first question has to do with the real relevance and novelty of the present archaeological revolution described by Kristiansen. The two previous scientific revolutions in archaeology were indeed decisive for the development of the discipline. The first one in the mid-nineteenth century actually allowed for the emergence of archaeology as a science, finally separating it from antiquarianism. The second one in the midtwentieth century goes hand in hand with the rise of New Archaeology, 
which proposed a truly new way of studying and understanding the past. Although I do see the potential of archaeometry for the transformation of our knowledge of the past, I do not think that it is actually promoting a different understanding of it, at least not on a revolutionary scale. The first two scientific revolutions implied radically new sets of ideas regarding society, time and the archaeological record. I find it hard to see any of this in the coupling of cutting-edge natural science methods and archaeology today. Quite the opposite: with some remarkable exceptions, including several of the archaeologists mentioned by Kristiansen and a few others (e.g. Jones 2004; Llobera 20II), my impression is that archaeometry has made many people lazy - and justified their laziness. Why should we try to think deeper and in a different way when all these methods tell us how the past actually was? They tell us exactly what they ate, where they came from, which diseases they suffered from. What else do we need?

The author puts a lot of emphasis on a totally different understanding of mobility and connections in the past made possible by archaeometric procedures. I would contend that it is not archaeometry that has made this understanding possible. It is the esprit du temps. We live in the network society (Castells 1996), a world where time and space have collapsed, where mobility is greater than ever and economic, cultural and political globalization mark the rhythms of each and every society. Networks, connectivity and mobility are the buzzwords of the social sciences and the humanities: from cultural geography to literary studies. As archaeologists, I am sure that we would be finding mobility without isotopes as well. In fact, we do: there is a lot of interest in mobility in archaeological subfields where scientific methods are not so widely used or needed, such as classical, historical and contemporary archaeology (Horden \& Purcell 2000; Van Dommelen \& Knapp 20I2; Beaudry \& Parno 20I3). What Kristiansen sees with excitement, I see with some concern. I fear that we may end up finding again a past modelled on our own present.

My impression is that we are finding too much movement in the past or at least that we are making too much fuss out of the movement that we find. Of course people (and things, and ideas) moved: there were migrations, exogamy, long-distance trade, pilgrims, peddlers, wandering holy men and women, war raids and travelling mercenaries. We knew that already without hard sciences (even if some processualists tried to deny mobility for a while). But the network-globalization paradigm prevents us, in my opinion, from grasping the actual nature of movement in the deep past as well as in many non-Western societies in the present. Ian Morris (2003) already defended, in a critique of Horden and Purcell's 
book, that it is necessary to understand the different rhythms of the ancient Mediterranean, with its episodes of connectivity and disconnection, movement and stasis, acceleration and deceleration. This is a perspective that could be shared by two historians that understood well the alterity of the past and its different rhythms - Braudel (1958) and Leroy Ladurie (1974). Jonathan Friedman (2002) has noted how the mobility paradigm is very much in tune with both the ideology of global capitalism and the lives of cosmopolitan academics. There is nothing strange, therefore, in archaeologists finding mobility in Prehistory today. In fact, they found it before. Interestingly, during the second half of the nineteenth century and the early twentieth-century movement was all over the place. Australians travelled to Eastern Africa with their boomerangs, African hunters arrived to Iberia with their arrowheads, Mycenaean architecture influenced the monuments of Wessex. Is it a coincidence that evolutionary and diffusionist archaeology saw their heyday during the Age of Empire and the first cycle of globalization?

My biggest concern, however, is not with archaeometry or mobility, but with what I see as an unconscious exclusionary tactic in Kristiansen's paradigmatic discourse. The situation that he describes is presented as the great revolution in archaeology. For me it is not the revolution; at best, $a$ revolution. I do not have any problem with people fighting for their paradigm and utopias, as long as they do not try to impose them as the single possible way of doing archaeology -or rather, the only way of doing good archaeology. My archaeology is different, although it can perfectly cohabit (indeed coalesce!) with Kristiansen's. I am not so sure, however, that he or his colleagues, in his desire to find scientific convergence and consensus, will be so magnanimous with other approaches. My archaeology, which I believe I share with many, is less fascinated with isotopes and radiocarbon, and more with the possibility of breaking the temporal limits of archaeology, dissolving divisions between past and present; an archaeology that can study the deepest prehistory as well as modernity, even the present (Harrison 20II) - there is not much room for the recent in Kristiansen's revolution. It is an archaeology that is more interested in opening the range of questions that we ask of the archaeological record, than with the devices that we use to make those questions answerable. It is an archaeology that welcomes many "esoteric theoretical models with minority status". Not only the new materialisms (Witmore forthcoming) that Kristiansen is eager to accept, but also alternative ontologies, indigenous archaeologies, decolonial thinking, feminism, queer theory, political archaeologies, Critical Theory (capitalized) or the archaeologies that reflect on the relationship between the discipline and the arts. These are all perspectives that 
have proposed new questions and raised new problems for archaeology, but that may not fit easily in the third scientific revolution of archaeology. The archaeology in which I believe overflows disciplinary limits as well, not just to walk together with biology and physics, but also with philosophy, anthropology, geography, history and cultural studies. And when I say walk together, I envisage an archaeology that instead of passively foraging from other fields, enlightens them. An archaeology that is relevant, therefore, not just because it manages heritage, works with communities and is conscious of its public role, but that is relevant because it is intellectually powerful. Because it helps us think and problematize society (past and present) as much as anthropology or philosophy, but in its own way. An archaeology, in sum, that produces theoretical insights and ideas for others to share and not just knowledge of the deep past (González-Ruibal 20I3). To be sure, Big Data can contribute much this archaeology, as do isotopes and radiocarbon, but it can also be done without them.

My questions also include a practical worry: will I be allowed to do my archaeology under the new revolutionary regime? This is not a mere rhetorical question. By "allowed" I mean: will there be funding for projects that do not fit the model proposed in the article? Will there be positions opened in universities and research institutions? Postgraduate and postdoctoral fellowships for those who take a different path? Furthermore, what happens with those of us who fail to attract the large (and scarce) amount of funding needed for systematic DNA analyses or isotope databases? Are we condemned to do second-rate archaeology? Or even worse, what happens with those thousands of archaeologists who do not even have the chance to apply for funding in places like Africa, the Middle East, or Latin America? In my archaeology, there is no problem with one working in a provincial university or tiny museum in a bankrupt country. One can still do first-class science. However, in Kristiansen's revolutionary archaeology, there does not seem to be much room for Third World practitioners, no more, at least, than there is for an astrophysicist in the Central African Republic. This is a pity: unlike the natural sciences, the social disciplines were (are?) still a somewhat democratic sphere of knowledge. I wonder, then, what is the political economy behind the paradigm proposed in this article? Will it aggravate the divide between North and South, the poor and the rich? Will we allow economically-disadvantaged archaeologists to participate in the big debates only as foot soldiers in a colonial army of data-providers? Of course, grand narratives are still mostly produced in the North, despite efforts by the World Archaeological Congress to redress the trend, but this situation will be more and more acute if we agree that the only 
progressive and cutting-edge archaeology is the one that needs millions (or at least hundreds of thousands) to be properly done.

Apparently, my lack of optimism for the brave new world places me in the "dark side of globalization", with resented neo-nationalists and perhaps some jihadists as well. But I cannot help but feel that Kristian Kristiansen's optimism sounds a bit too self-congratulatory: it is a celebration of the world as it exists now (for those who fare well). A world in which scientific paradigm, funding and academic establishment are seamlessly intertwined and inhabit a particular geography. Coming from a different place in the political, economic and academic world, I find it difficult to share his scientific utopia. I only hope that he will accept others.

\section{REFERENCES}

Beaudry, M. C. \& Parno, T. G. (Eds). 2013. Archaeologies of Mobility and Movement. New York: Springer.

Braudel, F. I958. Histoire et sciences sociales: La longue durée. Annales: Histoire, Sciences Sociales I3 (4):725-753.

Castells, M. 1996. The Rise of the Network Society: The Information Age: Economy, Society, and Culture. Oxford: Blackwell.

González-Ruibal, A. (Ed.) 20I3. Reclaiming Archaeology: Beyond the Tropes of Modernity. London: Routledge.

Harrison, R. 20II. Surface Assemblages: Towards an Archaeology in and of the Present. Archaeological Dialogues, I8(2): I4 I-I6I.

Horden, P. \& Purcell, N. 2000. The Corrupting Sea: A Study of Mediterranean History. Oxford: Blackwell.

Jones, A. 2004. Archaeometry and Materiality: Materials-based Analysis in Theory and Practice. Archaeometry, 46(3):327-338.

Kristiansen, K. 1998. Europe before History. Cambridge: Cambridge University Press.

Le Roy Ladurie, E. 1974. L'histoire immobile. Annales: Histoire, Sciences Sociales 29(3):673-692.

Llobera, M. 20I I. Archaeological Visualization: Towards an Archaeological Information Science (AISc). Journal of Archaeological Method and Theory, I8(3):193-223.

Morris, I. 2003. Mediterraneanization. Mediterranean Historical Review, I8(2):30-55.

Van Dommelen, P. \& Knapp, A. B. (Eds). 20I 2. Material Connections in the Ancient Mediterranean: Mobility, Materiality and Identity. London: Routledge.

Witmore, C. forthcoming. Archaeology and the New Materialisms. Journal of Contemporary Archaeology. 